ఠ

\title{
Prognostic impact of lactic dehydrogenase to albumin ratio in hepatocellular carcinoma patients with Child-Pugh I who underwent curative resection: a prognostic nomogram study [Erratum]
}

Gan W, Zhang MX, Wang JX, et al. Cancer Manag Res. 2018;10:5383-5394.

On page 5390, the following text should have been included in the "Acknowledgments" section: "Wei Gan, Mei-Xia Zhang, Jia-Xing Wang, Yi-Peng Fu, Jin-Long Huang, Yong Yi, and Shuang-Jian Qui contributed equally to this work and should be considered as co-first authors."

\section{Publish your work in this journal}

Cancer Management and Research is an international, peer-reviewed open access journal focusing on cancer research and the optimal use of preventative and integrated treatment interventions to achieve improve outcomes, enhanced survival and quality of life for the cancer patient. The manuscript management system is completely online and includes a very quick and fair peer-review system, which is all easy to use. Visit $\mathrm{http}: / / \mathrm{www}$.dovepress.com/testimonials.php to read real quotes from published authors. 